\title{
Calendar feasts: Politics of adoption and reinstatement ${ }^{1}$
}

\author{
Mare Kõiva
}

\begin{abstract}
Calendar feast system, the changes within the system and factors responsible for them present an important research topic in the study of the contemporary societies in the Soviet-influenced area. This paper elaborates on the trends of invention and reinvention of feasts in the first Republic of Estonia (1918-1940), after World War II (in the Soviet Socialist Estonian Republic) and since the re-establishment of the independent Republic of Estonia (1991). In the late $19^{\text {th }}$ and early $20^{\text {th }}$ centuries the structure of feasts in Estonia underwent profound changes due to modernisation and urbanisation. The article describes some important feasts (disguise traditions, student feasts, Christmas, etc.), and invented holidays like for example Mother's Day. In the 1920s, a system of state, national and public holidays was created; after 1946, national feasts established during the first republic were banned, Christian feasts were excluded from public holidays, and invented feasts were inserted from the common communist calendar (Women's Day, Red Army Day). In the 1960s, fairs, international days dedicated to certain professions (fishermen, miners, etc.) and public festive days emerged. The 1990s saw media-propagated newcomers (Valentine's Day, St. Patrick's Day, Halloween), and a reinvention of Walpurgis Night (volbripäev) and Mother's Day. The present study of the calendar feast system reveals that 1 ) the celebration of feasts follows a nonlinear model of behaviour (as seen in continuing celebration of unofficial feasts among one's family), 2) the contemporary system of feasts is highly institutionalised; the celebration of official feasts is canonised, and 3) the importance of church feasts has constantly decreased under the influence of the secularised society.

Continuously introducing new holidays which aimed at constructing identity and fostering humane values was characteristic of the $20^{\text {th }}$ century. Significantly, people yearned to take part in entertaining holidays and festivities. The demand brought about village days and local gatherings, including fairs, festivals, celebrations of new holidays, and other events.
\end{abstract}

Key words: Estonian calendar feasts, ritual year, Christmas, Mother's Day

1 I am grateful for the financial support provided by the Estonian Ministry of Education and Science (target financed research project No. SF0030181s08). 


\section{Introduction}

The system of calendar feasts is a construction created by the authorities rather than originating from among the people. It has an important role in defining the values of the members of a certain society. It is also a tool for creating national identity and the basic rationale for celebrations and feasts.

Feasts are undoubtedly a state's means of manifestation - as important as the flag, anthem and other official attributes. An American researcher of time and calendar, Eviatar Zerubavel (2003), has described the practice of establishing political power through the system of feasts. Also Gabor Barna, the Hungarian scholar studying the ethnology of religion, formulated the role of state power in his research:

The state organisation is an institution not only for administration but also for the exercise of power. The feast culture of a state power reflects the goals projected before the community. The political culture of the given regime can also be observed in the feasts (Barna 2011).

Estonia is a perfect example of a European state where holiday celebrations in the $20^{\text {th }}$ and $21^{\text {st }}$ centuries have been influenced by four different political regimes (Russian Empire, the first Republic of Estonia, Soviet Socialist Republic of Estonia, and finally the newly independent Republic of Estonia). It is noteworthy that a significant portion of changes in the $21^{\text {st }}$ century have been brought about, in addition to global influences, by directives and initiatives of the European Union.

As one cannot ignore political influences in addition to cultural, social and economical factors when observing changes in the calendar system, the article discusses feasts that display different degrees of institutional involvement, politics of adoption, invention (cf. Hobsbawm 1983; Halbwachs 1992), and reinstatement / reinvention process. Besides, the models of behaviour relating to holidays that have either lost their status or become banned will be under discussion.

As background information, it is important to know that Estonian territory was very monoethnic until 1946. ${ }^{2}$ Estonian calendar customs are characterised also by their division into mainstream Lutheran and Orthodox background systems in the mid-19 ${ }^{\text {th }}$ century. Orthodox calendar customs arose mainly following a trend of religious conversion that took place at around the same time. Regardless of the fact that Orthodox churches had by that time been built almost everywhere in Estonia, the Orthodox Church and its calendar feast system

${ }_{2}$ Ethnic Estonians constituted $88 \%$ of the population, with national minorities constituting the remaining 12\% (cf. Katus, Puur, Sakkeus 1997). 
mostly dominated on the western islands; it was also observed in the eastern part of Estonia where there was a mixed population of both Estonians and Russians. As before World War II Russians formed only $8 \%$ of all the inhabitants in Estonia, it was natural that churches were established primarily for Estonians and services were held in Estonian, although in the south-eastern part of the country services were conducted in both Estonian and Russian, switching from one language to another during the ceremony.

Estonia, which was different from the nearby eastern areas by its confession, language, as well as the fact that the region had for a long time held a special cultural-economic status because of the local Baltic German population, started developing its national holiday system in 1918. During the end of $19^{\text {th }}$ century and in the early $20^{\text {th }}$ century, the structure of feasts in Estonia changed mainly because of the influences of modernisation and urbanisation (for same tendencies, see Etzoni \& Bloom 2004: 5; Aveni 2004). Major changes were introduced in the structure of the state and its national feasts after the independence in 1918. At the same time, the importance of church feasts constantly decreased in the increasingly secularised society. The changes in economics minimised the need for agrarian rituals and festivities. In the early $20^{\text {th }}$ century, some new feasts were invented (e.g. Mother's Day and Labour Day, see also below in the section on holidays during the first Republic of Estonia).

After Estonia became independent in 1918, the Lutheran Church remained the state church. The Estonian Orthodox Church became divided into two branches in 1924 on the basis of whether it obeyed Constantinople or Moscow. The western islands, mainly Orthodox by religion, were well integrated with the rest of the country also in terms of holidays, which was hardly the case with south-eastern Estonians, who observed a completely different calendar system ${ }^{3}$. In general, the first Republic of Estonia separated the state and the church, and religious education became voluntary at schools. A significant feature was that the Orthodox minority (the subordinate group) got more folkloristic attention than the dominant Lutheran group.

As the hypotheses for this study, I propose that:

1) Two independent dynamic models of collective behaviour operate in the cultural space: the linear model supported by the state, which helps to create and inscribe new festivities (also state feasts), behavioural manners and identities into the society, and the heterogenous nonlinear model, which continues, at the level of family and social networks, to observe earlier traditions and to preserve values connected with these. Similar tendencies are certainly valid for ethnic groups that have survived a crisis, undergone the decline of an em-

3 The churches of Constantinople, Greece, Romania, Finland, the Baltic States, and Poland adopted the new calendar in 1924 (Moss 2012). 
pire, as well as gained or lost their statehood. Concrete personal behavioural strategies vary and, at least in the case of festivities and celebrations, there is a fusion of both these behavioural models and choices;

2) People, living their everyday life, have played their part in preserving, continuing, inventing / reinventing, and interpreting the traditions. I propose that this is highly dependent of political processes. Besides, also intellectual resources are involved in the creation and staging of calendar feasts.

My aim is to outline some processes characteristic of the Estonian ritual year, and to examine what happens to calendar practices when new and alien cultural practices interact with the local ones. First, I will describe the calendar system and its most popular features at the beginning of the $20^{\text {th }}$ century, i.e. during the first Republic of Estonia. Secondly, I will address the various celebrations in the calendar system after World War II (the period under the Soviet rule), and thirdly, I will provide the general description of the tendencies connected with ritual year during the re-established Estonian Republic.

\section{Estonian calendar system at the beginning of the $20^{\text {th }}$ century}

Before gaining independence in 1918, the main holidays for Estonians were fairs, church holidays, and the celebrations of the birthdays of Tsar's family. Estonia started to re-develop its state and national holiday system after gaining independence in 1918. Eric Hobsbawm distinguishes between three types of invented traditions, each of which have a distinctive function: a) those establishing or symbolising social cohesion and collective identities, b) those establishing or legitimatising institutions and social hierarchies, and c) those socialising people into particular social contexts. The first type has been most commonly referred to and often taken to imply the two other functions as well (Hobsbawm 1983: 9).

The most important national holidays during the first republic were February $2^{\text {nd }}$ (anniversary of signing Tartu Peace Treaty), and February $24^{\text {th }}$ (publication of the document titled the Manifesto to All Peoples of Estonia, which declared Estonia an independent democratic republic). As of 1934, the unofficially celebrated Victory Day (June 23) was added to the list of national holidays to celebrate the victory over the Baltic Landeswehr. On this day, a military parade was held and war casualties were commemorated all over Estonia at the monuments erected in the honour of the War of Independence. 
Different regions displayed special local features of celebrating calendar feasts. This formed a basis for the local identity. The islands and southern Estonia differed from the other parts of the country as to their wide variety of traditions. The islands alongside with western Estonia displayed cultural similarity to Scandinavia, having been influenced by historical contacts; southern Estonia had similar features to the Baltic Latvian culture, the north-eastern and south-eastern parts of Estonia were influenced by the Fenno-Baltic and partially also Slavic culture. The calendar traditions of this period had many special local features like specific food, clothing, and different celebration customs.

Important church, domestic and popular feasts at that time were Christmas, Shrovetide, Easter, Whitsun and St. Johns Day (jaanipäev). Christmas was associated with the oldest pagan traditions due to its Estonian name 'jõulud' (Yule was a Low German / Scandinavian name for the celebrations of the holidays of the season in general), a proposition which was put forward during the national movement in the $19^{\text {th }}$ century. This trend was supported by folklorists (e.g. by M. J. Eisen, who collected and published bulky volumes of folklore) and it continued throughout the $20^{\text {th }}$ century, despite the fact that the political power did not approve of it. The new name for the period around New Year's Eve, accepted by the Soviet power, was 'näärid' - also an old name borrowed from the Low German language, designating New Year".

It was noteworthy how disguising traditions (primarily St. Martin's Day and St. Catherine's Day) were adapted into the modern urban settlements and communities of that time. This meant that the structure of traditions and the masks themselves had to be adjusted, songs modernised, whereas the clothing style did not change much. People who disguised themselves were given money and urban presents (e.g. sweets).

The most popular holidays associated with the tradition of wearing masks and mumming occurred in the period between November and Easter. Throughout Estonia (except for the Orthodox south-eastern Estonia), the most important disguising and mumming holidays with rich customs and regional idiosyncrasies were the eves of St. Martin's Day (November 10) and St. Catherine's Day (November 23) (cf. Kõiva 2013). Already centuries ago, this was particularly diverse in western Estonia and on the islands, and shared similarities with the corresponding customs in Scandinavia (Christmas and New Year's goats, whips, etc.; see Eike 2007) or other wide-spread customs (Three Kings; cf. Simpson \& Roud 2000).

The traditions of celebrating St. Lucia's Day were somewhat popular in the area settled by the Estonian Swedes in the $19^{\text {th }}$ and the beginning of the $20^{\text {th }}$

4 Christmas and spring feasts have been discussed in numerous other studies (Eisen 1931; Eisen 1932; Kõiva 2005; Kõiva, Särg, Vesik 2004, and therefore they are not treated at length here. 
century. Within the last 15 years the custom has spread in Tallinn and in the revitalised area inhabited by Estonian Swedes, but in both places it is supported by some institutions and it is not sporadic.

On St. Thomas Day (December 21), according to old traditions of the western mainland and the islands, Thomases moved in the neighbourhood - young men wearing white clothes who were looking for beer which was being brewed around this period. Another tradition, even more popular, involved making the so-called Black Thomas or Grime Thomas (a straw or rag doll), which was then taken out and secretly placed behind the neighbour's door or taken out of the village (Tedre 2007). This was initially, in the ancient layer of traditions, meant to symbolise dirtiness and laziness, and taking The Grime Thomas figure to other households was a way to fight against these vices. Besides, this was the day when usually the stove stones in the sauna were washed clean of the soot that had accumulated over the year, and this was then suitably used for staining the figure. The custom of making a figure of Grime Thomas out of old rags is sporadically alive even today, but now it is considered just a joke and the ancient magical meaning had disappeared already by the first decades of the $20^{\text {th }}$ century.

Wearing masks at Christmas strictly remained the privilege of adult men. Groups of men went from household to household disguised as the Bucks. Sometimes the Bear and its Tamer or the Crane joined them. During the New Year's Eve, the Bucks and the Bears moved around once again. A specific feature of the animal disguise was that their visit included many verbal elements, although from time to time a musician accompanied them and played dance music. The masked men gave a dance performance to the household (sometimes also inviting the people to join in the dance) but on the whole there was no singing. Elsewhere in western Estonia, young masked men walked from house to house, begging for a sip of beer.

Wearing masks and mumming on Easter used to be more widely known. During the $20^{\text {th }}$ century it was a characteristic feature of the tradition in western Estonia and on the islands. Mummers in animal or bird costumes visited people to wish them good luck or health. For example, a 'goose' visited families to birch them for good health on Maundy Thursday and Good Friday.

Another masked creature characteristic of the region was the Meat Woman, sometimes called Meat Kai, who first appears in texts recorded in the $19^{\text {th }}$ century. Meat Woman was a personification of Lent and was believed to keep guard of how people observe fasting and work prohibitions, and is therefore similar to the personification of hunger around New Year. A woman who peeped through windows during Lent before Easter made sure that nobody did forbidden 
needlework or broke the fast. According to a popular saying, she would break the neck and pull out the guts of whoever is caught at a forbidden activity.

The first republic saw the invention of some new holidays (Mother's Day, Labour Day / May Day) - these were person-focused holidays (both were introduced in America in the $19^{\text {th }}$ century by women activists who by then had finally acquired national support). Mother's Day was introduced in Estonia also by women's movement. The song lists and celebration programmes that were distributed primarily at schools finally bore fruit when the day was nationally recognised and officially celebrated in the 1930s (Kõiva, Särg \& Vesik 2004).

The workers' day on the $1^{\text {st }}$ of May was legalised with less resistance around the same time by the liberal-minded and socially sensitive people. It was initially based on the idea of equal social rights, opportunities and freedom for everybody.

An ethnic religion (Taara belief, taarausk) created at the beginning of the $20^{\text {th }}$ century (Vakker 2012) aimed at introducing religious traditions partly connected with folklore. This was a thoroughly invented tradition, created by a small group of military people who borrowed some religious customs from folklore but mostly improvised the tradition without relying on any previous beliefs. Taara-believers celebrated St. John's Day and other feasts among themselves. At the same time, the 1920s was a period when people tried to revive old life cycle traditions. Traditional wedding and child christening customs were adapted and reintroduced. It is obvious that the traditions of urban life and these of urban intellectuals differed from the annual ritual traditions of rural people. But people living in the countryside also became aware of the new adaptations, and for example student songs were popular and became part of the collective traditions. Beside Estonian student corporations, Estonian schools developed their own specific customs, some of which have been preserved for more than a century already.

\section{Estonian calendar traditions under the Soviet rule}

Before describing the interaction between the celebration of holidays prescribed by the authorities and those practiced by the people among family and friends, we must have a closer look at the general nature of changes caused by power. From the perspective of significant memory fields that played a part in this process, it is important to remember that there were two massive deportations (one right before World War II and the other in 1949) which had a direct influence on the collective memory of Estonians, as well as the fact that more than a third of all Estonians and some indigenous ethnic minorities (Estonian Jews 
and Swedes, as well as other groups) were extinguished, forced to escape, or left the country voluntarily during the war. ${ }^{5}$

After World War II, the population started to change very quickly. It is important to mention several migration waves as they influenced the ritual year too. Only a few migration segments which directly influenced cultural and ethnic composition of the country will be referred to in this article. The successors of former migrants (Russian Estonians and their descendents who had migrated to Russia in the $19^{\text {th }}$ century; they had by then lived for about twenty five years in Soviet Russia) were sent back or came voluntarily from other Soviet countries to Estonia to be political leaders and officials (incl. establishers of the Communist Party and the cell leaders of the Young Communist League). This was a part of the political tactics of the federal state. According to $\mathrm{H}$. Kulu, more than 50,000 descendants of nineteenth century Estonian emigrants migrated from the Soviet Union back to Estonia in the 1940s (cited by van Ham \& Tammaru 2011). This group of people had a significant role in restructuring and sometimes initiating extreme radicalism in the Estonian economic and cultural system.

Some twenty thousand or more Russian Ingria Finns who were subject to extermination in the 1930s (Anepaio 1999) returned from deportation sites, being freed after the death of Stalin. The same applied to roughly a thousand Tatars (see Tatari keel 2004), who left the prison camps and arrived in Estonia due to ethnic persecution in Russia, and also to Jews from Russia who fled because of anti-Semitism in their former homeland.

The extensive migration was further supported by campaigns that advocated expanding communist construction sites and mines, and bringing the military industry (so-called post box factories) and permanent military units into Estonia. The country had become the western border of the Soviet Union, which meant that the coastal areas and islands belonged to the military. Secret military bases were established and civilian population was resettled from their original homes near these bases, or had to live in a border zone that had limited access. The proportion of (foremost) Russians or people speaking Russian increased due to immigration, by 1950 constituting as much as $40 \%$ of the whole population (van Ham \& Tammaru 2011). All these factors, together with the arrival of new religious and ethnic groups, led to a series of fast changes in the population structure. At least some Estonians kept hoping that the Soviet rule

5 With the beginning of the Soviet occupation of Estonia in 1940, Jewish cultural autonomy and Jewish organisations were terminated. Teaching Hebrew and Yiddish, and lectures on Judaism and Jewish culture, were banned. All Jewish schools were closed and 430 Estonian Jews (10\% of the Jewish community) were deported to Siberia in the course of the mass deportations of June 1941 (The Jewish Community in Estonia). 
would soon come to an end through an intervention by the West. Repressions and change only made the holidays which were unfavourable by the authorities more treasured by the Estonians.

The Soviet calendar system was imposed on Estonians at the period when it had already been developed for 30 years and the basic holidays were already fixed. Eviatar Zerubavel refers to the great revolutions that often strive to start a new era by reforming chronology, among other things. As an example, he talks about the Great French Revolution and Russian October Revolution, both of which radically changed the calendar (cf. Zerubavel 1981; see also Zolotova 2002). The transmission to a new time system started with introducing the Gregorian calendar (February 1, 1918). The Russian Orthodox church favoured the same time system, but later reinstated the Julian calendar. The subsequent radical calendar reforms were partially related to the country's economic status: from 1918-1929 the week lasted for 5 days, from 1929-1939 for 6 days, and in 1940, the 7-day week was established in order to ensure a steady economic growth (Shilova 2007). In the new Soviet calendar, every year had two numbers that were used parallelly: the first indicated the number counted from Common Era (CE, the equivalent of Christian era traditionally marked as $\mathrm{AD}$ ), and the second from the establishment of the Soviet power (ibid.).

In Estonia, major changes were made in the calendar system mainly after 1946. These consisted of excluding the previous state and national holidays and also Christian feasts from the list of public holidays. Invented holidays from a relatively stabilised communist calendar like the Red Army Day, $1^{\text {st }}$ of May, and October Revolution Day were publicly celebrated. The introduction of days dedicated to Soviet heroes and victories also meant that some of formerly important holidays like Mother's Day were no longer celebrated. Mother's Day was later replaced by Women's Day on March 8 (see Lubecka 2013: 92, this volume, for additional thoughts on invented holidays). Many previously active students' organisations and their celebrated days became prohibited as well.

In the 1950s, the public holidays in Estonia included extensive celebrations of St. John's Day with song- and dance festivals, open-air plays and other performances. Communal swinging, singing, decorating towns with birches as well as selling national food and beer was borrowed from the older fair customs. Several central holidays were celebrated similarly, in an organised manner, including vastlad (Shrove Tuesday), and St. Martin's and St. Catherine's Day, which supported their celebration at homes. The popularity of the latter two may be vested in a linguistic rather than a spiritual aspect; this is to say, the names (and holidays) were adapted to the Estonian culture (respectively Mart and Kadri) already in the $14^{\text {th }}$ century, when these feasts became suitably blended with the local pagan customs, and it had nothing to do with a particular affinity 


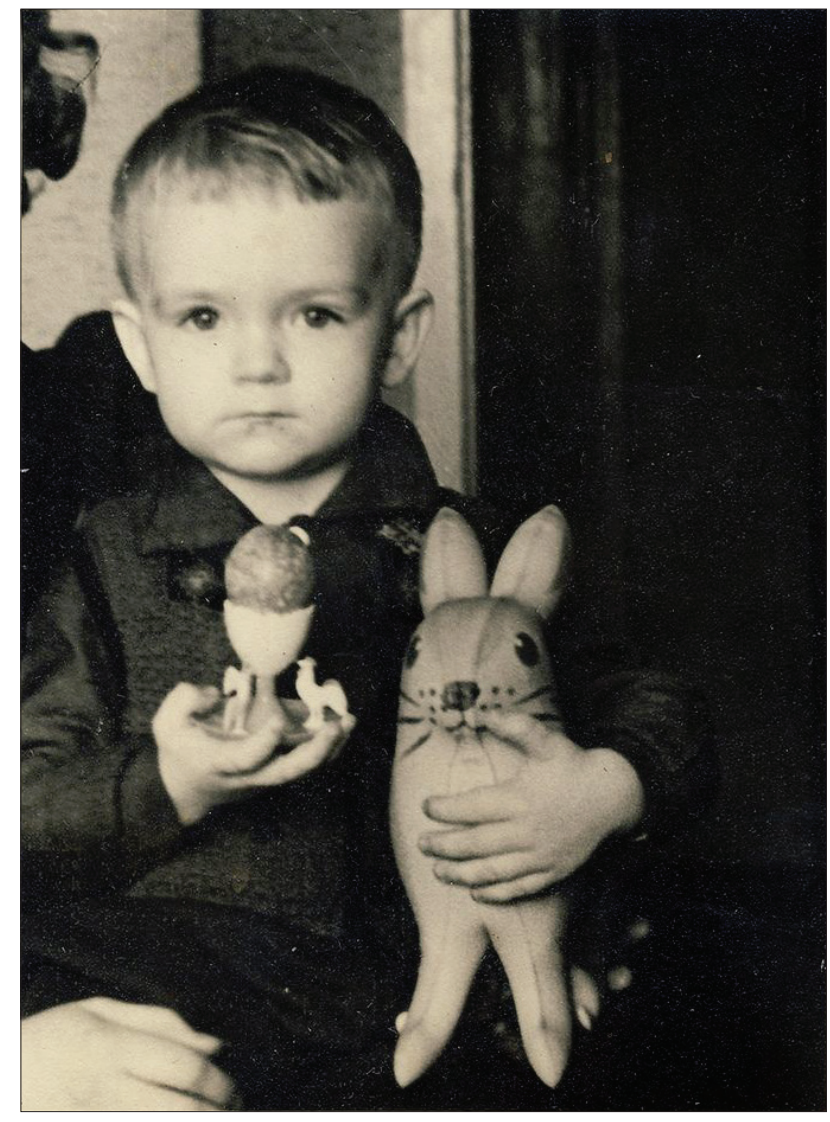

Figure 1. Easter. I bought this from an antique shop, I like it a lot. There is a well-behaved boy on this picture looking straight in the camera as was asked, but this look is almost hypnotising for the viewer. Egg cups were rare during Soviet time, but inflatable rabbits were massproduced in the factory "Tegur". And the boy also has another popular toy - hen pecking grain (beginning of 1970s, photo by Agnes Joala).

to the saints. As both of these masking feasts are celebrated towards the end of the year, it may have be connected with the traditional period of disguising among young men, signifying a time of initiation rites when young couples were welcomed into the world of grown-ups. During the Soviet times, St Martin's and Catherine's Days as well as Shrove Tuesday were celebrated in culture houses and schools but also at homes; people were given a day off on St. John's Day. The official politics in regulating these holidays needs further study.

Perhaps the biggest difference in comparison to other countries was the high level of secularisation before World War II, which softened the painful shock other nations had to undergo due to church feasts (e.g. Easter, see Figure 1) 
being excluded from the official calendar. Individual celebration of church feasts was popular already during the first Republic of Estonia, and most families kept celebrating church and national feasts at home like before. Naturally they tried to return to older systems of social life and festivities at any opportunity. This was successful in more liberal years but then became prohibited again as a consequence of stricter policies.

How did the non-institutional domestic celebrations of holidays develop? There have always been persons and groups who are not interested in calendar feasts or are too exhausted from physical work to celebrate anything, so they have rather vague ideas about holiday traditions. At the same time, there are also always groups and individuals who (consciously or unconsciously) follow the official policies and accept the changes in calendar holidays. It is obvious that people simultaneously preserved older traditions and went along with new ones to some extent. The invention of new holidays and their acceptance took time. J. Helslooth describes the long and controversial process of introducing Mother's Day into Dutch culture, concluding: "Through the combined effects of the introduction of Mother's Day in primary schools, through extensive media coverage and commercial advertising, the new rituals became ever more widely known and gradually less novel, thereby slowly but steadily becoming "traditional" (i.e. more or less inevitable), whether as something to negate or with which to comply" (Helslooth 2007: 219).

As seen in the following examples, it becomes obvious how state institutions, also on the level of schools, influence the continuation and popularity of feasts also in Estonia:

New Year's Eve was the only holiday our family celebrated from the official Soviet calendar (this only included a late dinner, perhaps a glass of champagne, and a permission for children to stay up as long as they wanted). Children naturally made gifts and cards for the mother and granny on Women's Day (and bought something if it happened that dad gave them money), but we didn't even have the chance to cook something on our own in the kitchen because our granny made sure we wouldn't be able to make a mess there. And our mom kept repeating that Women's Day is rather a day for humiliating women as it clearly indicates that all other days are men's days. I only remember that once the new constitution was adopted in the Soviet Union and the Constitution Day was moved from December 5 to October, my family was pleased because this day coincided with the birthday of my great-aunt Alma, so we could then drive to Haiba to celebrate Alma's birthday. Woman, born in 1955, Tallinn - Lilleküla ${ }^{6}$.

${ }^{6}$ Here and later: all the interviews are conducted by the author in 2012. 
New Year's Eve was special because guns were fired and occasionally fireworks as well. All people gathered on streets at midnight where friends and strangers congratulated each other when the New Year arrived. I remember especially clearly visiting my relatives at Järvakandi when I was a preschool child - my uncle, who was a glass maker, had a gun, and to my ears it seemed like the whole country would break apart from the bangs. Woman, born in 1954, small town in central Estonia.

Occasionally we "poured fortune" during nä̈̈rid (New Year's Eve). It was fun. If we weren't able to get any lead, e.g. in the 1980s, we used paraffin wax instead - hot wax was poured into a bucket of cold water - we could still tell our fortune. When decorative candles went out of sale, they were poured from the ends of big white household candles. Perfume and detergent bottles became candle moulds; people learned how to dye them by domestic means. These were very nice gifts for family and friends, but foremost they were nice for lighting during holidays. Woman, born in 1954, Tartu.

Liisa Vesik has pointed out that in the $20^{\text {th }}$ century, many folk holidays turned into important family holidays, which united and strengthened family ties, village communities, relationships between godparents and godchildren, teachers and pupils, friends and relatives (cf. Vesik 2000: 189). An increase of subjectivity and individual creativity, establishing a personal emotional connection with holidays and their celebration, and introducing new, sometimes agrarian elements into urban homes were global trends (compare Santino 1995; Aveni 2004).

Fairs, which had been an important economic-cultural event in the last centuries and a marker of locality, were revived in the 1960s. The first such events were a mixture of ethnic / traditional and contemporary / modern aspects. I remember from my childhood (in mid-1960s) the first fair that took place at my neighbouring town Jõgeva. People traded with national food, took part in different traditional competitive games and listened to a student band where Nikoli Laanetu, Priit Pärn, ${ }^{7}$ and other known figures played. This made a simple agrarian event diverse and attractive. Many of such fairs also presented a legal possibility to trade the products produced in private households which otherwise were taken to Russian markets, primarily to Leningrad. For example, exotic plants were exchanged at Türi Flower Fair which was first held in 1977, and this became the peak event of the year for many - it was an exciting occasion for which people came from all over Estonia, having planned it long ahead, in order to sell and buy plants and other agrarian products.

7 N. Laanetu - a biologist, P. Pärn - a famous caricaturist and filmmaker. 
The integration of international occupational holidays (Children's Day, Teachers' Day, Museum Day, Theatre Day, Fishermen's Day, Miners' Day, etc.) into the collective awareness of the Soviet peoples as of the 1960s was among new social trends. I presume these changed the importance of calendar holidays, at least in urban settlements, and started to involve different social strata to a growing extent. In the 1970 s, many celebrations and competitions were powered by the local initiative. The Games of Lake Võrtsjärv, initiated by the agricultural holdings' managers of Võrtsjärv lake and led by Kalev Raave, became very popular among the people who lived in the area. Fishermen's Day, Miners' Day and other secular holidays were celebrated widely by the people working in the trade as well as others. Celebrations were organised by the local community, with the primary aim to have fun and spend quality time. Thus, attractive holidays initiated by and aimed at the rural people developed alongside similar holidays in the urban areas. Holiday traditions which concerned specific professions, however, were not publicised as widely as they were in the countryside (e.g. truly influential Tartu Vanemuise Theatre Conference held on the International Theatre Day, March 27).

We can see the same tendencies in the ritual year traditions of the Soviet Russia: public celebration of the more entertaining festivities connected with older church feasts was tolerated in Russia after Stalin's death; so was the reinvention of several traditional feasts. Russian researchers have characterised the years 1960-1970 as the period of introducing entertaining holidays that would fit in the urbanised environment of the Soviet cultural space. The celebration of clearly ethnically oriented new holidays became common, targeting mainly the dominant ethnic group, the Russians, held at town squares and in culture centres in the countryside. These included Russian Winter (Russkaya zima) and the Russian Birch feast (Prazdnik russkoi berezki; added about a decade later) (e.g. Zolotova 2002: 166 ff.).

We will now turn to discussing the role of student organisations in the Soviet-era ritual year. Tartu University (est. 1632) has a long history of student corporations (fraternities and sororities), some of which were re-established in the early $20^{\text {th }}$ century. These are notable for their rich customs. Belonging to a student organisation was considered one of the markers of intellectuality in the pre-war society. In spite of prohibitions on organisational and public celebrations, an aggregate of students' associations was developed during the Soviet times, although it acted on different basis and only some of the previous student union features could be retained. Students' cap (tekkel) $)^{8}$ was connected with students' identity. There was a symbolic competition between the universities

8 Different universities had their own caps; so did highschool students. The common schoolcap marked the belonging to a particular youth community. 
(i.e. between those of Tartu and Tallinn). It was considered very important to own a student cap, differently coloured for different faculties and course years. Some of the earlier traditions also remained. The students' processions carried a high significance for the people. The beginning of the 1970s is considered a period of increased political control as in these years, students' procession carrying torches became officially prohibited.

Under the Soviet rule, many of the obliterated holidays were still celebrated in the family circle. Not all official holidays were received with equal enthusiasm. For example, Women's Day was institutionalised in the 1960s, and many traditions originally related to Mother's Day, an earlier holiday, were transferred to the $8^{\text {th }}$ of May. Nevertheless, Mother's Day, which used to be celebrated institutionally (in the form of festive gatherings) and then rooted into domestic family traditions, remained important for some families throughout the Soviet times, visible also in the excerpts from the interviews below:

Unlike Women's Day, which was to be organised by us, the children, and towards which the grown-ups had a rather ironic attitude, Mother's Day was the only holiday led by father. To be precise, he organised picking the flowers and bossed the children around: "Make sure you draw cards for your mother and grannies!" Everybody loved to draw, so it wasn't a punishment that we had to make the cards. [...] We definitely had to pick the flowers from the forest. We went there with our dad on the Saturday before Mother's Day, and always to Veskimetsa. Dad always bought a cake for Mother's Day, and although we ate most of it, but the centre of the cake, which in the event of birthdays belonged to the birthday boy or girl, was for mom this time. Woman, born in 1954, Tallinn.

International Women's Day, the best income day for florists, was made fun of as a somewhat hypocritical holiday, but it was still celebrated (compare Helsloot 2007 about Mother's Day in the Netherlands). However, Father's Day was never successfully introduced, besides, it was tied to the army's anniversary day, February 23, by the Soviet authorities - one reason for the opposition was the desire not to associate father's role with the military system. This holiday almost coincided with the anniversary of the Republic of Estonia, which originally signified the day of independence of the first republic - another uncomfortable aspect for the people.

Celebration of Christmas displayed the same tendencies as other holidays (see Figures 2 and 3 on page 74). Christmas was still celebrated at home (about Christmas during Soviet time cf. Hiiemäe 2003; Kõiva, Vesik \& Särg 2004). Here are some examples that reveal how Christmas was celebrated: 
I think Santa Claus visited all my classmates (I'm talking about Tallinn School No. 46, today's Pelgulinna Gymnasium). Later I have heard my contemporaries (but not my classmates) say that on Christmas Eve a feast was prepared, whereas presents were left for children on New Year's Eve, or that Christmas was hidden behind another family event or celebrated afterwards at the week-end. At least no one (from my classmates) dared to say that Santa Clause did not visit them. [...] For us, the children, Christmas period started already at the beginning of December when we wrote wish lists to Santa Claus, or, before we learned how to write, whispered our wishes into mother's or father's ear. It was noticeable that it was Christmas time and that it preceded the next holiday, näärid (the official seasonal holiday in the atheist Soviet Union). We wrote wish lists many weeks before Christmas, but it didn't actually set us in the Christmas mood just yet. [...] And Christmas trees were sold before Christmas - we always had a tree at home. But at that time, they weren't sold at each store, rather at markets. Our market place was Kalinini market located at the current Mööblimaja (furniture store). Christmas trees and spruce branches were sold there already on December $20^{\text {th }}$. We usually bought it on December $23^{\text {rd }}$, because you never know what circus there might be on December $24^{\text {th }}$ - and it stood behind our house, in the back corner of the yard. [...] The Christmas tree that was put up at Võidu (Victory) Square, now called Vabaduse (Freedom) Square, was lit up only after Christmas, but store windows were decorated earlier. The most pleasant memory about this is the window of a toy store located at either Karja or Viru Street [...] which had full decorations for a long time. And what fine decorations these were: there was a small circulating stage with dolls standing on it, each one holding a present (one had a package of colourful dominos) and these dolls disappeared behind a plywood spruce and then appeared again. I could watch this thing move endlessly, especially because there weren't usually many stores that would have moving window decorations. Besides, toy store windows were anyway most attractive (except the office of Aeroflot at the corner of Võidu Square with its TU-1149 model, which didn't move, but looked very real). [...] When we went to secondary school, Christmas was also "celebrated" at school. This meant that someone took candles and matches along; the number of these was different each time, but sometimes there were enough candles for all desks. And so teachers were tested - how they reacted when they stepped into the dark classroom, candles burning on desks and spruce branches here and there (not only

9 TU 114 - The Tupolev TU-114 Rossiya is a turbopropeller-powered long-range airliner designed by the Tupolev design bureau and produced in the USSR from May 1955. 


\section{Mare Kõiva}

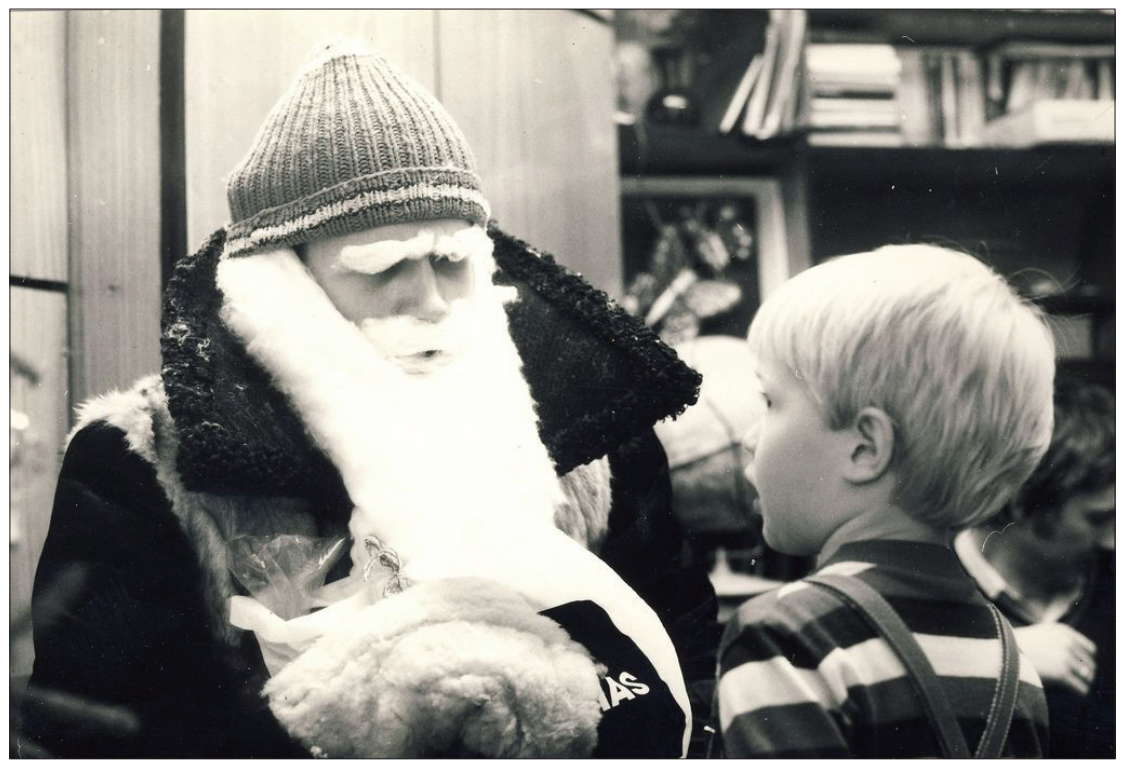

Figure 2. My father kept a ferret furcoat in the wardrobe, and it was used only during Christmas. We turned it inside out to make a costume for Santa Claus. Father never wore that coat because it was too heavy, but it was fine to wear it only as Santa. We lended our Santa also to our neighbours (1985, photo by Agnes Joala).

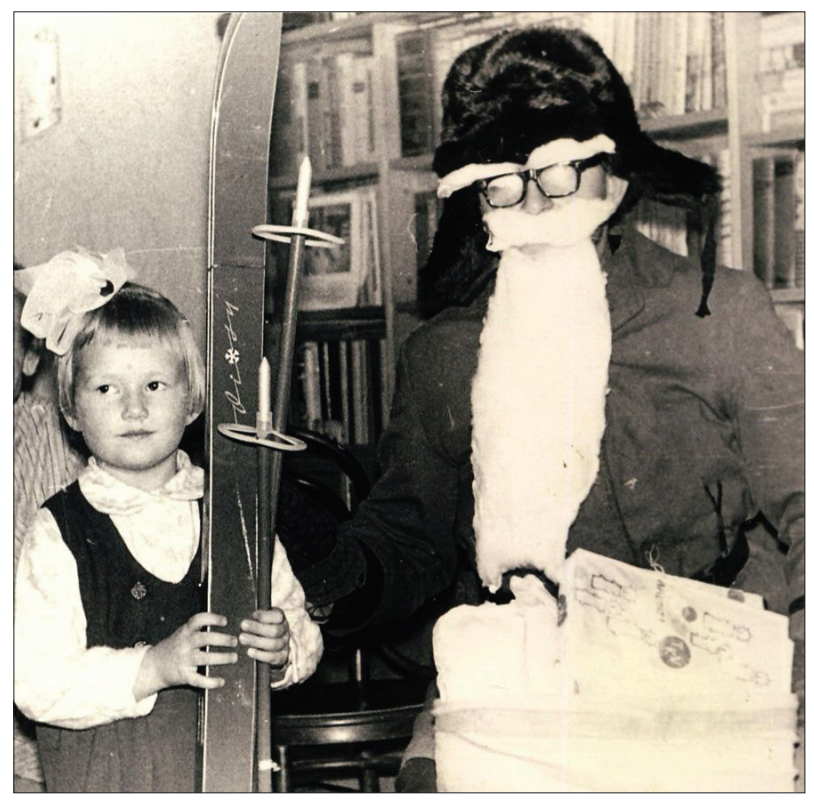

Figure 3. Our Santa Claus and Eeli in 1970. Santa is wearing a brand new rabbit fur hat (1970, photo by Agnes Joala). 
on the teacher's desk). Most teachers just told us to blow out the candles and that was that. Around that time ${ }^{10}$ people also started to go to church on Christmas Eve. It was not prohibited at home and not spoken about at school. Woman, born in 1955, Tallinn.

Although different national groups did not accept other groups' customs, certain unification and adaptation still occurred:

Even during the Soviet times, when half of the sales personnel were Russians, they said that December 24 is estonski prazdnik (Estonian party), Estonians hotšet (want) pork, I make pork at home because it's Estonians' prazdnik. Woman, born in the 1970s, Tartu.

\section{New tendencies in the Republic of Estonia}

In the early 1980s and 1990s (before regained independence), the system of holidays had changed in Estonia. After the socialist political system collapsed, the Soviet monuments, street names, and place names changed. At the same time, the change in the celebration of traditions never displays sharp changes (except for state holidays): they have fluid borders. We can observe the continuation of major holidays like Christmas, New Years Eve, Easter (Kõiva 2005), St. John's Day, St. Martin's and St. Catherine's Days, and other holidays throughout the $20^{\text {th }}$ century. The list of present-day national holidays includes, in addition to an increasing number of days dedicated to historic events, the renamed May 1 (Spring Day, kevadpüha), some church feasts, including November $2^{\text {nd }}$ (All Souls Day), and a day dedicated to education and national symbolism (March 14, Native Language Day invented in 1999). New holidays advertised in the media gained popularity: Valentine's Day, St. Patrick's Day, Halloween, and Walpurgis Night (volbripäev). After 1990s, Mother's Day and St. Lucia's Day, as well as revived medieval festivities and rituals like the so-called electing of the Count of May (Maikrahv), were celebrated. The Mediaeval and Hanseatic Days have given a new opportunity for former Hanseatic towns to celebrate holidays from the mediaeval or even earlier period. This includes a wide selection of events - fairs, entertainment, cultural events. It is an opportunity to make music, dress up, perform small plays, trade with art, handicraft and ecoproducts, and participate in parades, wearing suitable costumes. The mediaeval festivals, where culture and trade are mixed in tradition in a very productive way, have now peaked, although they have been popular for some time already.

${ }^{10}$ End of the 1960s - beginning of the 1970s. 
The majority of calendar holidays are celebrated in educational institutions on all levels. They form a part of the programmes at cultural centres and other institutions. The most popular festivities are Christmas and New Year's Eve parties, Shrove Tuesday, Women's Day and Mother's Day. Schools have adapted and celebrate a number of international and local holidays, among which there are some holidays that have been forgotten a long time ago and were (re)invented only in the twentieth century. For example, hingedepäev - All Souls Day - was the first calendar holiday to have an Estonian name in the medieval calendar in the $13^{\text {th }}$ century (Mänd 2004), but despite its original prominence, it was largely merged to a more general "time of souls" (hingedeaeg) as the scope of Catholic influence diminished. It was again officially reinstated in 1992 in the Republic of Estonia. Since the holiday had some political support, it was initially uncertain whether the holiday will shove aside other traditional cemetery traditions and commemoration days of departed relatives.

Let us have a closer look at some features of reinvented Walpurgis Night (volbripäev), which is the carrier of two different traditions. Firstly, the celebration of April $30^{\text {th }}$ may include organising a witches' feast (this is especially true in schools and day-care centres, but also in towns and villages) and provides an opportunity for wearing a costume in public, staging minor improvisational plays, and simply having fun. While little time and effort is spent on preparing and wearing masks on Walpurgis Night, wearing a stylised costume consisting of a few typical elements (witch's or wizard's hats, capes, and, most importantly, face painting) is still widely practiced. The popularity and availability of face and body paint is perhaps the reason why these have become widely used instead of masks. Since no other joyous public masking festivities are celebrated in the spring / summer season, the Walpurgis Night celebrations are all the more important. The adoption and reinstatement of Walpurgis Night has acquired a special significance in the tradition of Estonians but also among the local Russian-speaking minorities.

Secondly, April $30^{\text {th }}$ is connected with traditions of the student organisations, revived at the end of the $1980 \mathrm{~s}$, among them the public procession of students through the city of Tartu, and the very popular parody procession on the following day through Supilinn, which is a district near the city centre and has traditionally been the place for affordable students' rental apartments. The parody procession was the most popular student tradition also in the first half of the $20^{\text {th }}$ century. The students' rituals in Tartu follow a clear pattern: at 8 o'clock in the evening, the students march singing in a procession through the city. They go to the Town Hall Square, where they accept the keys of Tartu from the mayor, because for this night the power in Tartu is handed over to students. The procession then heads towards the main university building, 
where students greet the university rector with a song and the rector responds with a speech. Next, the head of the statue of the biologist Karl Ernst von Baer on Toome Hill is subject to ritual washing with champagne. Students also sing at the other monuments and then head to corporation buildings, which open their doors at midnight for visitors from other corporations and for non-affiliated students. The next morning, students take a boat down the Emajõgi River, drinking beer and singing, or finish the party with other rituals - for example, eating porridge together.

There is also a third way of celebrating the night, spread among those who are not students and who do not like crowded public events. They light bonfires in the company of family and friends, which attests to the incorporation of Walpurgis Night tradition into the general cultural tradition.

Student culture and its traditions have also been adopted in Tallinn, the capital of Estonia, by the new universities established in the 1990s. Regardless of that, student traditions have been most prominent and popular in Tartu, where the percentage of students is highest and where the traditional student feasts can be traced back throughout centuries. A current trend is the expansion of the student traditions, once characteristic only of Tartu, to other university towns.

The reinstatement process of local fairs, reinvention of the different forms of masking tradition, promotion of the older traditions by the followers of the ethnic religion maausk ('earth faith') and a long list of festivals and village days - all these features are similar to the trends in the ritual year in the first Estonian Republic. The main difference is that all that happened in the frame of two contrasting processes: the growing urbanisation during the first republic, and suburbanisation in the present day. The process of urbanisation started in Estonia in the beginning of the $20^{\text {th }}$ century, and by the $1930 \mathrm{~s} 30 \%$ of the population lived in towns. According to the Estonian demographics profile from $2012,69 \%$ of the inhabitants of Estonia live in towns, while third of them (ca 400 000) live in the capital (Estonia Demographics Profile 2013), but there is a gradual increase in suburbanisation which started already in the last decades of the $20^{\text {th }}$ century. This has resulted in a change in calendar traditions: adjusting celebrations to fit an urban setting was visible in the calendar year of the first republic, and from the end of the $20^{\text {th }}$ century there has been a move towards celebrating feasts in a suburban environment. 


\section{Conclusions}

There are many opposing and heterogeneous factors that affect the ritual year and traditions connected with it. The system of Estonian calendar holidays has changed considerably in the last hundred or more years. The official national holidays have followed the directions set by the political power, affirming its currently dominating discourse. Regaining independence brought along an increase in the number of national holidays, as the holidays of both republics were taken into account. ${ }^{11}$ It is obvious that an increasing number of state holidays connected with the more recent history and dedicated to independence are introduced into the public life. In addition to that, adding new holidays that are celebrated all over Europe, such as the ceremony for acquiring citizenship (and other celebrations concerning the relations of state and its citizens), is very common. The Estonian version of the ceremony includes a festive reception at the Town Hall, meeting with the representatives of state authority, giving out the certificates, and a concert. One of the new trends includes celebrating the day of one's land or town. This has led to a discussion among ethnologists, who have pointed out how difficult it is to find, choose, and establish such new holidays and understand what to celebrate and emphasise with this event - i.e. how to find content for a holiday (compare discussions about Sweden's Day in Petterson \& Ulfstrand 2007: 22 ff.; Gustavsson 2007: 191 ff.). As Hobsbawm (1983) has stressed, all these state holidays must establish or symbolise social cohesion and collective identities, and socialise people into particular social contexts.

It is also important to note that just a few religious holidays (e.g. those connected with saints) have been reinstated; instead there is a tendency to stress the importance of family relations. Some of these include the second Sunday of May as Mother's Day, the second Sunday of November as Father's Day, invented in 1988, and since 2010 the second Sunday of September as Grandparent's Day. In comparison, there is also a tendency in the Russian calendar to add saints and holidays dedicated to love, marriage, and other "soft values".

It was noticeable already from the 1960 s to 1980 s that people wanted and needed entertaining holidays and festivities, especially during summer, in addition to winter holidays. That is why the whole summer was and still is usually filled with fairs, festivities, festivals, new holidays, village days, social gatherings, or newly created cultural events (e.g. related to the day of some saint which has traditionally not been celebrated for centuries). Many of invented

${ }^{11}$ February 2 - Anniversary of the Tartu Peace Treaty in 1918; February 24 - Restoration of Independence in 1991, August 23 - European Day of Remembrance for Victims of Stalinism and Nazism, September 22 - Resistance Fighting Day; November 16 Sovereignty Declaration Day in 1988, and in 2013 a new state holiday - Veterans Day (April 23) instead of former St. George's Day. 
local festivals and days from the Soviet period (the Games of Lake Võrtsjärv, Fishermen's Day, and Miners' Day) are popular again.

Different communities, with their particular calendars and tactics for using them, undoubtedly exist side by side. The members of other communities may join in the celebrations of its neighbouring groups out of solidarity or curiosity. We can even say that celebrating holidays that are historically or ethnically alien to a certain group of people is part of a recent trend. Chinese New Year celebrations, becoming more and more popular each year, are a good example of that.

The contemporary system of holidays is highly institutionalised and the celebration of official holidays is canonised. The linear model supported by the state inscribed many state holidays into the Estonian society, but only a few of them came with a set of traditions and are celebrated also in the family circle. Nevertheless, there have been several holidays which were celebrated primarily among family members during the periods when they were looked upon unfavourably by the state. At the same time we can see how the reinstatement of holidays de-sacralised their essence (e.g. in the case of Mother's Day) or how the nonlinear model supports the celebration of some "Soviet" holidays (e.g. International Women's Day, or May 9, the Victory Day).

Variability, invention and creation of new rituals, as well as the preserving, reinvention and interpretation process was very rapid and intensive during the $20^{\text {th }}$ and $21^{\text {st }}$ centuries; it needed cultural adaptation and more intellectual choices than ever before. A continuing increase of new holidays directed at identities and humane values is a characteristic feature of the ritual year of the $21^{\text {st }}$ century. This is not a less political or symbolic activity than introducing other national holidays. Institutionalising and regulating the private sphere with state holidays carries a symbolic message.

\section{Manuscripts}

Interviews were recorded all in 2012, and are kept in the personal archive of the author. Photos - digital archives of Agnes Joala, Jalutuskäik ajas [A journey in time]. http:// jalutuskaikajas.blogspot.com/2012_12_01_archive.html, last accessed on 13 May 2013. 


\section{References}

Anepaio, Terje 1999. Soomlased. [Finns.] In: Viikberg, Jüri (ed.). Eesti rahvaste raamat. Rahvusvähemused, -rühmad ja killud. [A book of nations. Ethnic minorities, groups and fractions.] Tallinn: Eesti Entsüklopeediakirjastus, pp. 437-445.

Aveni, Anthony F. 2004. The Book of the year: A brief history of our seasonal holidays. New York: New York University Press.

Barna, Gabor 2011. In harmony with the new social order? Feasts and beyond representation: the case of Hungary. Poster. From Language to Mind. Tartu: ELM Scholarly Press.

Eike, Christine 2007. Disguise as ritualised humour in Norway: Past and present. In: Terry Gunnell (ed.) Masks and Mumming in the Nordic Area. Acta Academiae Regiae Gustavi Adolphi XCVIII (98). Uppsala: Kungl. Gustav Adolfs Akademien för svensk folkkultur, pp. 497-530.

Eisen, Matthias Johann 1931. Meie jõulud. [Our Yule.] Tartu: Matthieseni trükikoda.

Eisen, Matthias Johann 1932. Kevadised pühad. [Spring feasts.] Eesti Vabariigi Tartu Ülikooli Toimetused. B: Humaniora 27 (3). Tartu: Matthieseni trükikoda.

Estonia Demographics Profile 2013. Index Mundi. http://www.indexmundi.com/estonia/ demographics_profile.html, last accessed on 14 May 2013.

Etzoni, Amitai \& Bloom, Jared 2004. Holiday and rituals. Neglected seedbeds of virtue. In: A. Etzioni \& J. Bloom (eds). We are what we celebrate: Understanding holidays and rituals. New York: New York University Press, pp. 7-41.

Gustavsson, Anders 2007. Celebrations of national holidays in a Norwegian-Swedish border perspective. In: L. Midholm \& A. Nordström \& M. T. Agozzino (eds.) The ritual year and ritual diversity: Proceedings of the Second International Conference of The SIEF Working Group on The Ritual Year, Gothenburg June 7-11, 2006. Göteborg: Institute for Dialectology, Onomastics and Folklore Research in Göteborg, pp. 191-200.

Halbwachs, Maurice 1992 [1941]. On collective memory. Chicago: The University of Chicago Press.

Helsloot, John 2007. Vernacular authenticity: Negotiating Mother's Day and Father's Day in Netherland. In: P. J. Margry \& H. W. Roodenburg (eds.) Reframing Dutch culture between otherness and authenticity. Humpshire, UK: Ashgate Publishing Limited, pp. 203-224.

Hiiemäe, Mall 2003. Nõukogudeaegsed jõulud. [Christmas at the Soviet time.] In: A. Krikmann \& S. Olesk (eds.) Võim \& kultuur. [Power and culture.] Tartu: Eesti Kirjandusmuuseum \& Eesti Kultuuriloo ja Folkloristika Keskus, pp. 339-383.

Hobsbawm, Eric 1983. Introduction: Inventing tradition. In: E. Hobsbawm \& T. Ranger (eds.) The invention of tradition. Cambridge: Cambridge University Press, pp. 1-14.

Katus, Kalev \& Puur, Allan \& Sakkeus, Luule 1997. Development of national minorities. Republic of Estonia up to 1944. Trames 3 (1), pp. 221-246. 
Kõiva, Mare \& Särg, Taive \& Vesik, Liisa (eds.) 2004. BERTA: Eesti Rahvakalendri tähtpäevade andmebaas. [BERTA. The database of Estonian popular calendar.] Tartu: Eesti Kirjandusmuuseumi rahvausundi ja meedia töörühm. http://www.folklore.ee/Berta.

Kõiva, Mare 2005. Easter in Estonia. In: G. Mifsud-Chircop (ed.) First International Conference of the SIEF Working Group on the Ritual Year in Association with the Department of Maltese, University of Malta Junoir College, Msida, Malta Proceedings, Malta, March 20-24, 2005. Malta: Publishers Enterprises Group, pp. 340-361.

Kõiva, Mare 2013. The ritual year on the windy coast. Manuscript.

Lubecka, Anna 2013. Polish ritual year - a reflection of Polish cultural policy. In: L. Laineste \& D. Brzozowska \& W. Chłopicki (eds.) Estonia and Poland: Creativity and tradition in cultural communication, Vol. 2: Perspectives on national and regional identity. Tartu: ELM Scholarly Press, pp. 83-98.

Moss, Vladimir 2012. The Orthodox churches and the new calendar (1918-1939). http://www.orthodoxchristianbooks.com/articles/445/-orthodox-churches-newcalendar-(1918-1939)/, last accessed on 13 May 2013.

Mänd, Anu 2004. Pidustused keskaegse Liivimaa linnades 1350-1550. [Urban festivals in medieval Livonia 1350-1550.] Tallinn: Eesti Keele Sihtasutus.

Petterson, Ann \& Ulfstrand, Anna 2007. A Celebration of the national day in the name of history and antiracism. In: L. Midholm \& A. Nordström \& M. T. Agozzino (eds.) The ritual year and ritual diversity: Proceedings of the Second International Conference of The SIEF Working Group on The Ritual Year, Gothenburg June 7-11, 2006. Göteborg: Institute for Dialectology, Onomastics and Folklore Research in Göteborg, pp. 22-28.

Santino, Jack 1995. All around the year: Holidays and celebrations in American life. Illinois: University of Illinois Press.

Shilova, Irina 2007. Building the Bolshevik calendar through Pravda and Izvestiia. Toronto Slavic Quarterly, No. 19. http://www.utoronto.ca/tsq/19/shilova19.shtml, last accessed on 13 May 2013.

Simpson, Jacqueline \& Roud, Steve 2000. A dictionary of English folklore: Traditional beliefs, customs, myths, and superstitions. Oxford paperback reference. Oxford \& New York: Oxford University Press.

Tatari keel: Estonian Bureau of Lesser Used Languages (EstBLUL) 2004. http://www. estblul.ee/EST/Keeled/tatari.html, last accessed on 13 May 2013.

Tedre, Ülo 2007. Masks and mumming traditions in Estonia. A Survey. In: T. Gunnell (ed.) Masks and Mumming in the Nordic Area. Acta Academiae Regiae Gustavi Adolphi XCVIII (98). Uppsala: Kungl. Gustav Adolfs Akademien för svensk folkkultur, pp. 367-448.

The Jewish Community in Estonia 2013. http://www.telaviv.vm.ee/jewish_community_ in_estonia, last accessed on 13 May 2013.

Vakker, Triin 2012. Rahvusliku religiooni konstrueerimise katsed 1920.-1930. aastate Eestis - taara usk. [Attempts at constructing a national religion in the $1920 \mathrm{~s}$ and $30 \mathrm{~s}-$ taara belief.] Mäetagused 50, pp. 175-198. http://www.folklore.ee/tagused/nr50/vakker.pdf, last accessed on 21 May 2013. 
van Ham, Maarten \& Tammaru, Tiit 2011. Ethnic minority-majority unions in Estonia. European Journal of Population 27 (3), pp. 313-335, doi: 10.1007/s10680-011-9236-z.

Vesik, Liisa 2000. Tähtpäevad tänapäeva Kagu-Eestis. [Contemporary popular calendar dates in South-East Estonia.] In: K. Koreinik \& J. Rahman (eds.) A kiilt rahvas kynõlõs... Võrukeste keelest, kommetest, identiteedist. [But the lenguage was spoken... On the language, customs and identity of the vorrukesed.] Võro Instituudi Toimõtiseq 8. Võru: Võro Instituut, pp. 87-104, 181-206.

Zerubavel, Eviatar 1981. Hidden rhythms: Schedules and calendars in social life. Berkeley \& Los Angeles \& London: University of California Press.

Zerubavel, Eviatar 2003. Time maps: Collective memory and the social shape of the past. Chicago: University of Chicago Press.

Zolotova, Tatyana N. 2002. Russkie kalendarnye prazdniki v Zapadnoi Sibiri (konec $X I X-X X v v$.). [Russian calendar holidays in western Siberia (end of XIX-XX cc.).] Omsk: Omsk State University. 